\title{
Symbolic behaviour at places of social activity beyond the domestic area in the Ionian Neolithic
}

\author{
Georgia Stratouli \\ IZ' Ephorate of Prehistoric and Classical Antiquities, 16 Aristotelous Street, GR - 582 oo Edessa \\ stratman@panafonet.gr
}

\begin{abstract}
This paper suggests a reassessment of the role of caves during the Neolithic in Greece. Some of these cavities could have hosted performative and ritual events, or other kinds of social and/ or symbolic activities and, therefore, could be treated as forms of monuments. These issues are discussed on the basis of Drakaina Cave, located in the Poros Gorge on Kephalonia Island in the Ionian Sea. The archaeological evidence of the cave (e.g. the construction of lime plastered floors, the deliberate deposition of associated artefacts) is traced on three main scales: symbolism, monumentality, and the significance of the cave's landscape for Neolithic society. Moving away from the site, it is argued that the gorge of Poros itself was a powerful topographic feature, constituting a symbolic resource in the landscape and, thus, a valued site which contributed to the formation of the biography, identity and politics of the Neolithic community in the region.
\end{abstract}

IZVLEČEK - V članku predlagam, da se ponovno oceni vloga jam v grškem neolitiku. V nekaterih izmed njih so se morda odvijale predstave, obredi ali drugačne oblike socialnih in simbolnih dejavnosti, zato lahko te jame obravnavamo kot oblike spomenikov. O tem razpravljamo na primeru jame Drakaina, ki se nahaja v soteski Poros na otoku Kefalonija v Jonskem morju. Arheološko vsebino jame (konstrukcije z apnom tlakovanih tal, namerna depozicija artefaktov) raziskujemo na treh glavnih nivojih: simboliki, monumentalnosti in pomenu jamskega okolja za neolitsko družbo. Širše gledano skušamo dokazati, da je bila tudi soteska Poros s svojimi topografskimi značilnostmi vir simbolizma v pokrajini ter pomembna točka, ki je prispevala $k$ nastanku biografij, identitet in politike neolitskih skupnosti na tem področju.

KEY WORDS - Neolithic; Drakaina Cave; Ionian Islands; symbolic behaviour; landscape and monuments; social memory and identity

\section{INTRODUCTION}

Recent debate on archaeological theory has shifted interest towards reading material culture as part of the symbolic realm of a society (Hodder 1986). Moving from the study of the physical properties and practical uses of artefacts towards the search for more abstract symbolic meanings, many archaeologists have attempted to unravel and interpret the various ways through which a community expresses and constructs itself in time and space (e.g. Hodder 1991; 1995; Thomas 1996.55-83). However, many studies consider specific types of artefacts, such as figurines and ornaments, as the main objects of research on symbolic meaning (e.g. Gimbutas 1982;
Séfériadès 1995; Nikolova 2003.chps. 6, 9, 10, 14, 15). Moreover, such categories of material culture are thought to be the dominant symbols of Neolithic society and, consequently, the main mediators of social meaning. Meanwhile, other scholars suggest that the conceptual universe of a community could be directly accessible through other fields of analysis, such as architecture, or spatial arrangements and, thus, space and place (e.g. Parker-Pearson and Richards 1994; Kotsakis 1998).

In recent times, even the meaning of the term Neolithic has radically changed; at present, it is synony- 
mous with the development of new concepts of identity, community, time and space (Hodder 1990; Thomas 1991; Whittle 1996; Bradley 1998. 21). In other words, the Neolithic is not merely regarded as an 'economic entity', based simply on a switch from a hunting and gathering economy to new strategies of survival which supported the establishment of food production (Edmonds 1999). What is distinctive about this period is that social groups interacted with the landscape (Whittle 2003), constructing new social environments and creating 'homelands' through the practice of building and dwelling in settlements, land cultivation and exploitation, and a variety of social events (Bailey 2000). In this respect, the 'landscape' cannot be conside-

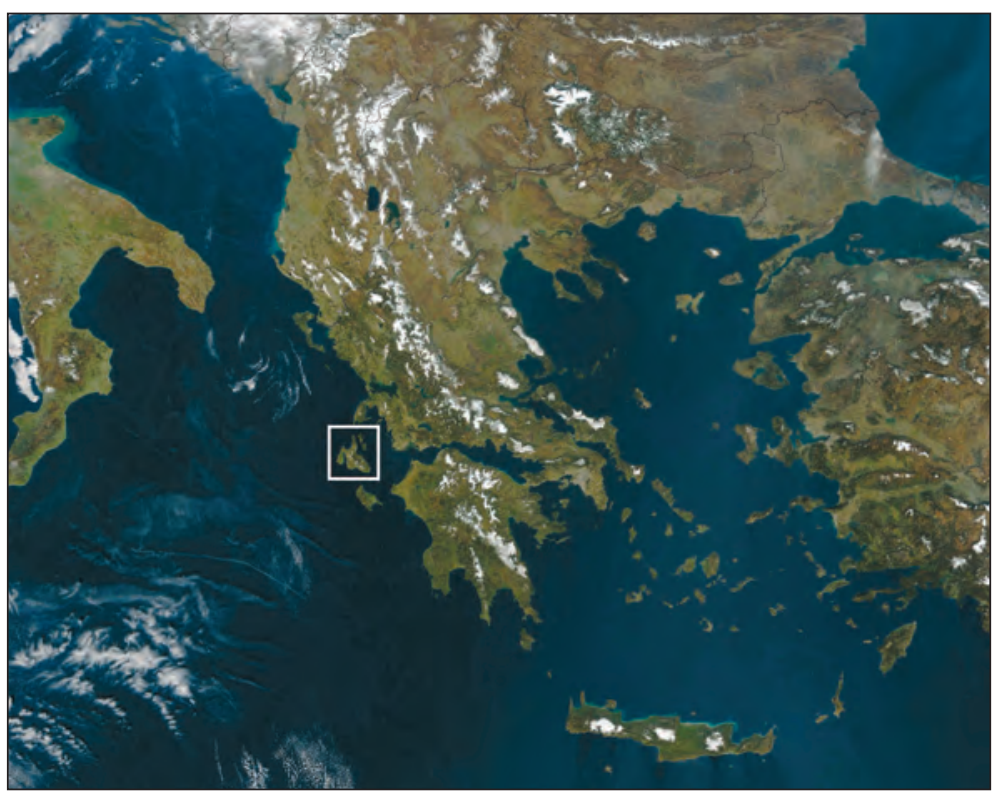

Fig. 1. Map highlighting the location of Kephalonia Island, western Greece. red as a terrain of economic significance only, supporting the survival of a community (e.g. Crumley 2002; Hill 2004). According to J. Thomas (2001. 181 ), it can be considered as "a framework for integrating many different forms of information and different aspects of human life". As C. Tilley (1996.161) suggests, the landscape is comprised of a series of locales (places), with particular social significances and embedded meanings. Actually, the meaning is produced in these loci by the dynamic interplay between people, artefacts, events and places (Thomas 2001.181). Architecture, myths, feasts, rituals, and almost any form of past action, are capable of binding people to certain places in which specific meanings are constructed and experienced (Basso 1996. 57; Tilley 1996.162). Monuments are such loci of special significance. Their study has gained ground in recent prehistoric studies, especially with regard to Neolithic Europe (e.g. Tilley 1994; Bender 1998; Bradley 1998; Edmonds 1999). In Greece, a developed interest in similar perspectives is not yet evident. A few approaches that discuss such issues restrict themselves to the study of habitation spaces, focusing on the social and monumental character of tell settlements (e.g. Kotsakis 1999; Nanoglou 2001). Indeed, it is accepted that the great typological variety of monuments (i.e. long mounds, cairns, causewayed enclosures, henges, barrows, chambered tombs etc; see Thomas 1991; Bradley 1998) which marked the prehistoric landscapes of many European regions (e.g. Britain, Hungary, Ireland) seem to be absent from the Balkans. We should perhaps consider other places as loci of such monumental value in the Neo-

lithic landscapes of this region. In recent years, the boundary between an 'artificial' or 'built' monument and a 'natural' landmark as perceived by a social entity as a place of special value has been called into question (e.g. Bradley 2000). Mountains, forests, clearings, rivers, lakes, swamps, rocks, and a variety of other 'natural' features may have been associated with particular events and activities (Tilley 1994. 38-9) and, in this sense, they could be seen as webs of meaningful places in the landscape (Tuan 1977. 239). J. Barnatt and M. Edmonds (2002) have recently discussed some Neolithic and Bronze Age caves in Britain, where funerary and ritual activity is evident, which could be treated as monumental sites.

A similar approach could be proposed for caves in Greece used in the Neolithic and, therefore, we should reassess the role of caves during this period. Some of these cavities could be valued locations and, thus, forms of monument. As it is widely accepted (e.g. Renfrew 1984.178-182; Hodder 1984; Thomas 1991.37; Tilley 1996), monuments constitute places of symbolic content, signifying both abstract and specific qualities. For instance, it would be interesting to explore how social memories and values are inscribed upon certain monumental loci, such as some caves in the Neolithic of Greece. Performative and ritual events, as well as other kinds of social and/or symbolic activities which might have also taken place in caves, could have strengthened social coherence and identity, or even supported acts of remembering and forgetting (van Dyke and Alcock 2003.2; Harrison 2004). 


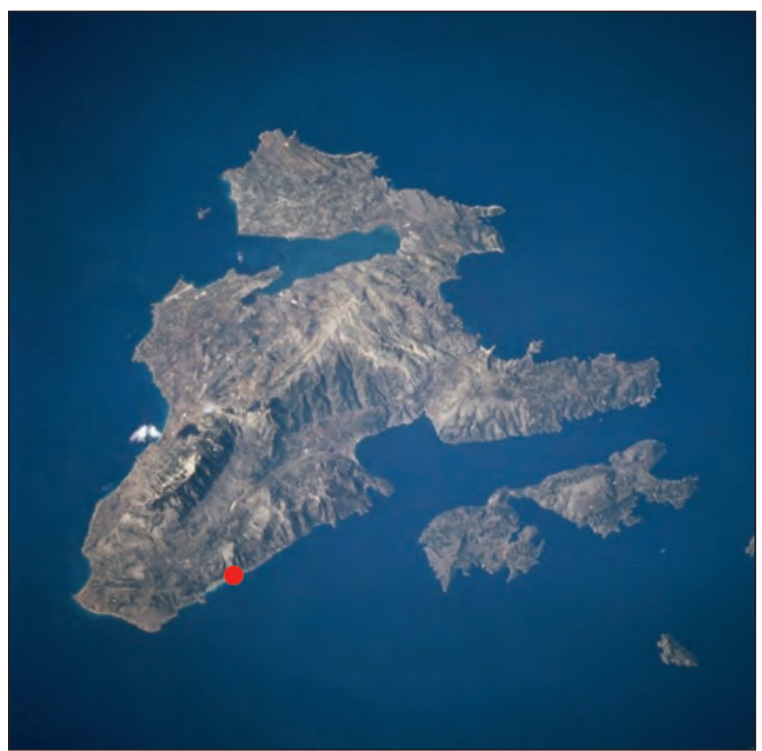

Fig. 2. Satellite image of Kephalonia Island showing the gorge of Poros, where Drakaina Cave is located.

I discuss this issue here on the basis of a particular cave in Greece, known as Drakaina Cave, where symbolic behaviour seems to be evident.

\section{DRAKAINA CAVE AND ITS NEOLITHIC CULTURAL RECORD}

Drakaina Cave is located in the south-eastern part of Kephalonia Island in the Ionian Sea, Western Greece (Figs. 1-2). The cavity lies at an altitude of c. 70 metres, in the impressive, steep-sloped Poros Gorge, at a modern village on the nearby coast.

At present, Drakaina forms a rock shelter extending over an area of approximately 90 square metres. Its geological history is complicated. High-tectonic activity in the region has resulted in the collapse of its roof, probably since late prehistoric times. Nevertheless, during its cultural history, Drakaina must have been an open cavity, occupying an area of no more than c.100 square metres.

The site has been excavated systematically since 1992 by the Hellenic Ministry of Culture - Ephorate of Palaeonathropology-Speleology (Chatziotou et al. 1995; Chatziotou and Stratouli 2000). Human activity on-site started at about the mid $6^{\text {th }}$ millennium $\mathrm{cal} \mathrm{BC}$, and has continued for many generations during the Neolithic, up to the beginning of the $4^{\text {th }}$ millennium cal BC, based on radiocarbon dating (Stratouli et al. 1999). Periodically, the cave hosted cultural activity for an even longer time, up to the mid $3^{\text {rd }}$ millennium cal BC (that is, the Early Bronze Age II). This period was followed by a long period, in which the cave was not occupied, as indicated by the accumulation of a naturally-induced layer lacking any evidence of archaeological remains. From the late $7^{\text {th }}$ century $\mathrm{BC}$ to the beginning of the $2^{\text {nd }}$ century $\mathrm{BC}$, the cave became a place of cult activity. More precisely, it was used as a local temple dedicated to Nymphs and Pan. Thereafter, the cave was abandoned until recently, when it was used as a sheepfold.

In Drakaina, an unusual practice for cave sites is documented: the construction of a series of lime plastered floors (Fig. 3) during both the Late Neolithic (ca. 5600/5500 - $4800 \mathrm{cal} \mathrm{BC)} \mathrm{and} \mathrm{the} \mathrm{Chalcolithic}$ (or the Final Neolithic, in terms of Aegean periodisation; c. 4800 - $3700 \mathrm{cal} \mathrm{BC).} \mathrm{According} \mathrm{to} \mathrm{the} \mathrm{micro-}$ morphological analysis conducted on-site (Karkanas 2002; Karkanas and Stratouli in preparation), the main raw material used for the construction of these floors was marl, in addition to pure Neogene limestone taken from outcrops in the vicinity of cave. After its collection, this material was transformed into lime through firing processes, i.e. into a new, light solid material, which made it rather easy to bring into the cave. There, it was mixed with water, and applied to the underlying deposit. Finally, as recorded in some samples, the surface of the floors was coated with pure lime, that is, with a form of plaster. The whole process seems to indicate that the manufacture of the lime plastered floors in Drakaina Cave was a product of special care and planning.

The careful investigation of the floor units has allowed us to conclude that, at least in some cases, the floors comprised stones (Fig. 4) and fragments of artefacts, such as large parts of grinders. In other cases,

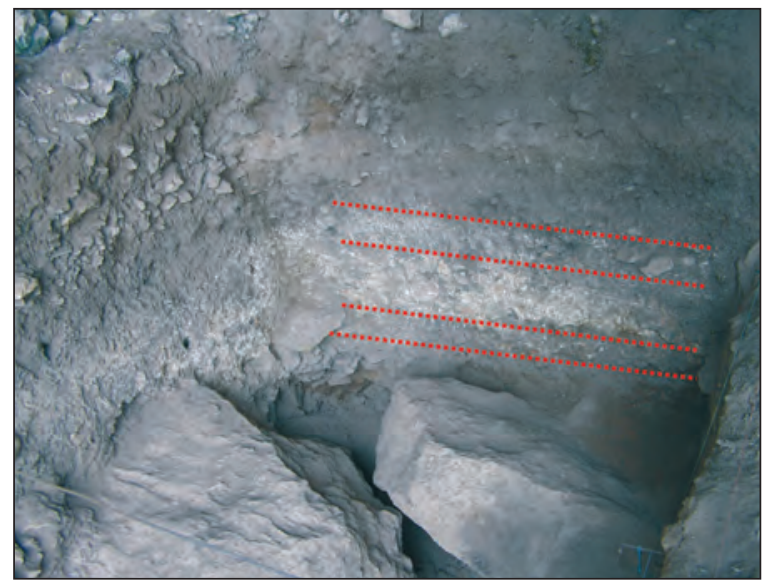

Fig. 3. Stratigraphic profile of Drakaina Cave, indicating the approximate level of constructed lime plastered floors. 
the floors included small stones from the cave environment and some quantity of clay, along with some chert flakes and small pieces of animal bone. In a few cases, the floor units incorporated fragments of architectural remains. Some of these pieces, judging from the plant, or wood impressions on them, may have been parts of sturdy wall constructions, traces of which have not been documented on-site, pointing to the fact that they were probably brought into the cave from nearby settlement(s) and deliberately deposited into the cave. In addition, other artefacts, such as half pots, or fragments of pottery, were also deliberately deposited in the floor sub-surface.

Based on the same micromorphological analysis, the deposits between the plastered floors comprised large quantities of dispersed wood ash, charcoal fragments, other charred plant material, and pieces of burnt bone. These were considered to be indicative of raked-out fire installation material (Karkanas 2002; Karkanas and Stratouli in preparation).

In addition, the deposits related to the floor sequence provided us with a large number of cultural remains. The bio-archaeological material comprises thousands of animal bones, the vast majority from domesticated species (Chatziotou et al. 1995; Kotzambopoulou in preparation). At least in certain cases, it is apparent that the recovered animal bones, which were mostly fragmented and burnt, or 'coated' with ash, were closely related to the partially preserved features of a possible fire installation function. A wide range of molluscs was also present, in addition to a few remains of fish and crab. All aquatic faunal remains in Drakaina could have been collected or fished near the cave (Theodoropoulou in preparation). Although the site has been systematically sampled for environmental data, Drakaina has provided us with a rather poor plant/seed assemblage. Three or four species of wheat were recorded,

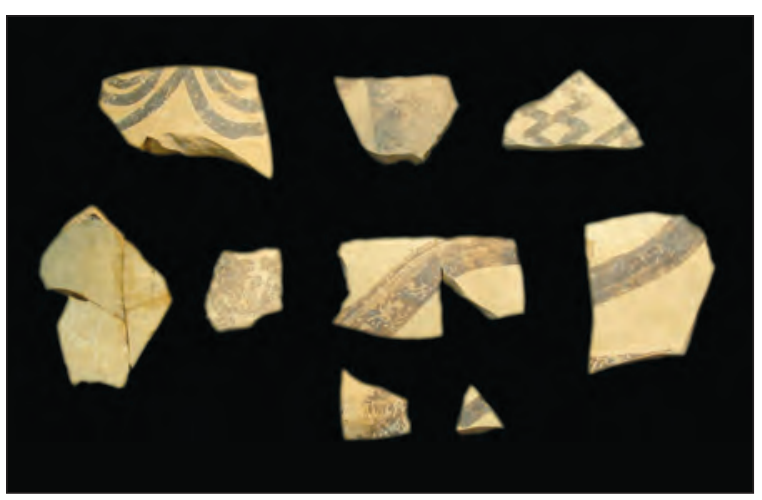

Fig. 5. Pottery fragments of dark-on-light ware from Drakaina Cave.

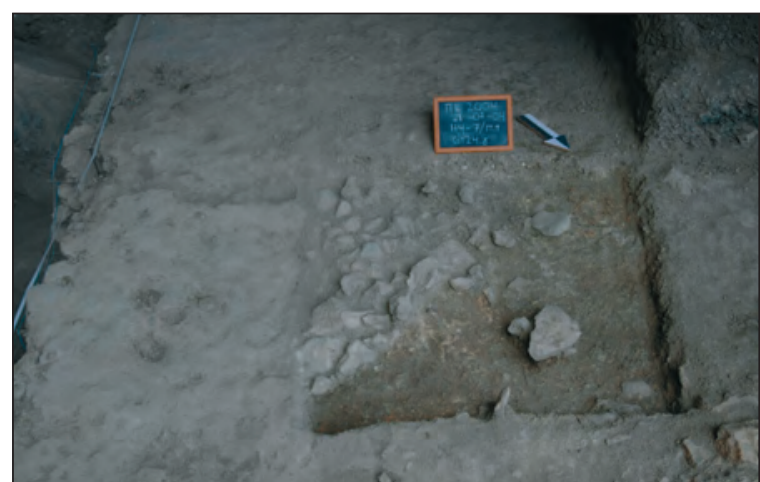

Fig. 4. View of the sub-surface of one of the constructed floors in Drakaina Cave. The stones depicted probably form part of the floor construction.

as well as two species of barley, a variety of pulses (which seem to have been as equally important as cereals), and a few fruits. No evidence of grain storage was documented on-site; most of the material involved seems to have been extensively processed before being brought into the cave and so could have been served easily for consumption, with no, or very limited preparation on site (Sarpaki in preparation). The general picture of the bio-archaeological remains unearthed in Neolithic Drakaina allow us to assume that various foodstuffs were consumed on site at intervals, probably during formal, or other feasts (cf. Dietler and Hayden 2001; Pearson 2003), and by no means during routine visits. In order to investigate these issues further and supplement the information provided so far, we have planned a more systematic micromorphological study of the deposits under question, coupled with chemical analysis, and organic residue analyses on pottery.

Also, the Neolithic deposits at Drakaina include a variety of artefacts, such as some large pots and numerous small and medium-sized clay vessels. Most are

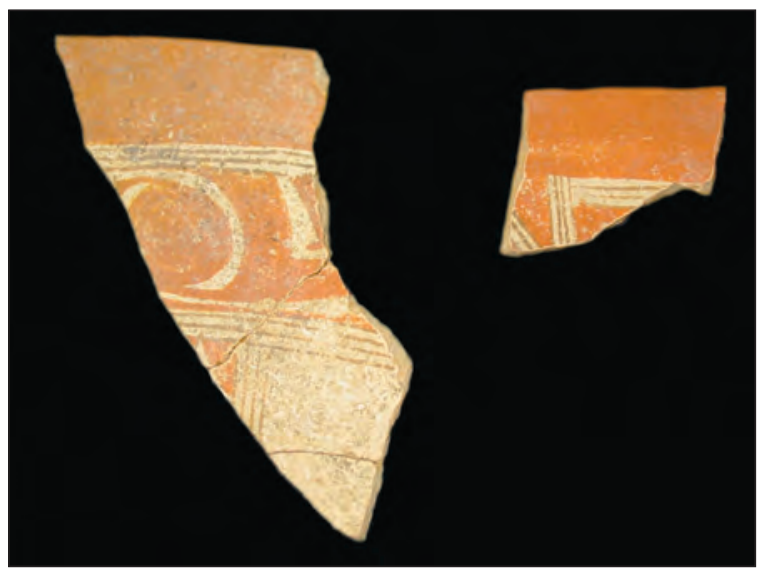

Fig. 6. Sherds of bichrome painted pottery from Drakaina Cave. 


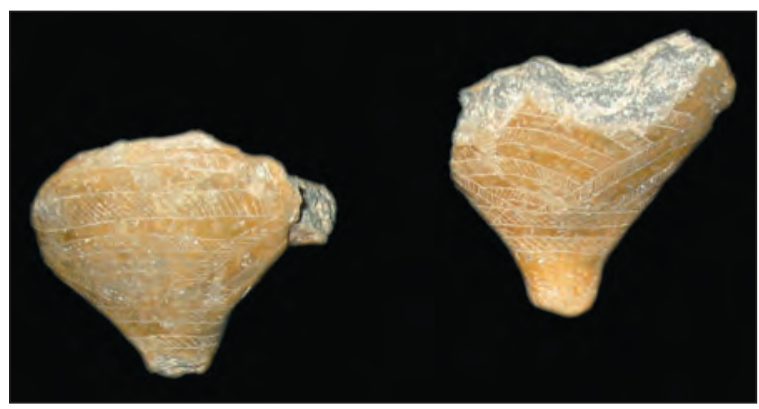

Fig. 7. Zoomorphic legs with incised decoration belonging to a so-called 'Danilo-scoop' from Drakaina Cave.

of 'good' quality, like those of black-burnished ware, or those of several patterned wares, that is, painted urfirnis, dark-on-light, polychrome, and painted crusted wares. Some of these vessels, according to their technological characteristics and raw material provenance analysis, are not of a local origin (Kiriatzi in preparation). It is worth noting that the largest quantity of pots, in particular those with patterns are extremely fragmented (Figs. 5-6). Thus, there are vessels represented by one, or a few sherds only. For example, the assemblage of painted urfirnis consists of approximately 140 sherds from some 35 different pots (Stratouli and Goudi in preparation). The same pattern is attested for other categories of decorated pottery, including the so-called 'Rhyta' or 'Danilo-scoops', a well-known type of vessel, with four zoomorphic legs and extended incised decoration (Fig. 7). This pattern of high fragmentation points to the practice of deliberately breaking pottery (cf. Chapman 2000). In some cases, it seems possible that pieces of painted/decorated pottery were deliberately brought to the site in fragments and deposited there. The same practices apply to other categories of artefact found in the cave.

Furthermore, a large number of chert tools, such as scrapers, burins, and macroblades, which were either fragmented or complete, was unearthed in Drakaina Cave (Andreasen in preparation). One such interesting lithic assemblage provided us with 187 projectile points of various morpho-functional classes (Fig. 8) (Metaxas in preparation). It should be stressed that, despite the evidence for in situ chert tool manufacture, some skillfully treated projectiles seem to have been brought into the cave as finished objects. This applies especially to projectiles of red chert which are of a local provenance, as well as to those of honey chert, a raw material which may have been imported to the island. Some other artefacts, such as several small-sized stone celts made of gabbro (Fig. 9), as well as discoid or cylindrical beads

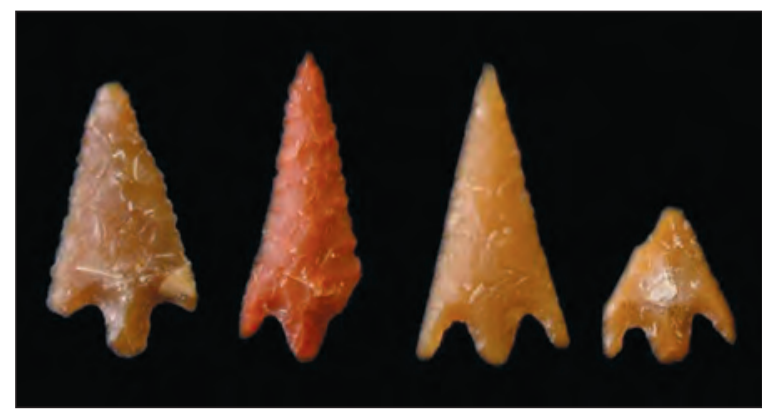

Fig. 8. Bifacial retouched projectiles from Drakaina Cave.

and button-like stone ornaments, the latter being made of talc (Fig. 10), were also transported to the island through inter-regional networks (Stratouli and Melfos in press). In addition, many beads made from various local shells, several fragmented rings/ bracelets, and a few anthropomorphic pendants of Spondylus gaederopus were deposited in the cave. Finally, it is worth mentioning the occurrence of a large assemblage of ground stone tools, comprising nearly 450 artefacts. This assemblage consists of grinding tools used in stable or mobile mode, small and large hammer-stones, and a great variety of pebble tools used for abrasion and/ or smoothing. A large number of these implements bear stains of reddish pigment, while other tools are coated with red dye (Fig. 11), or carefully encrusted with it (Bekiaris in preparation).

\section{Symbolic and monumental aspects of the site}

I now attempt to discuss further the archaeological record of Drakaina Cave, aiming to trace the meaning of practices that are evident in it, on three main scales: the symbolic behaviour at the site, the monu-

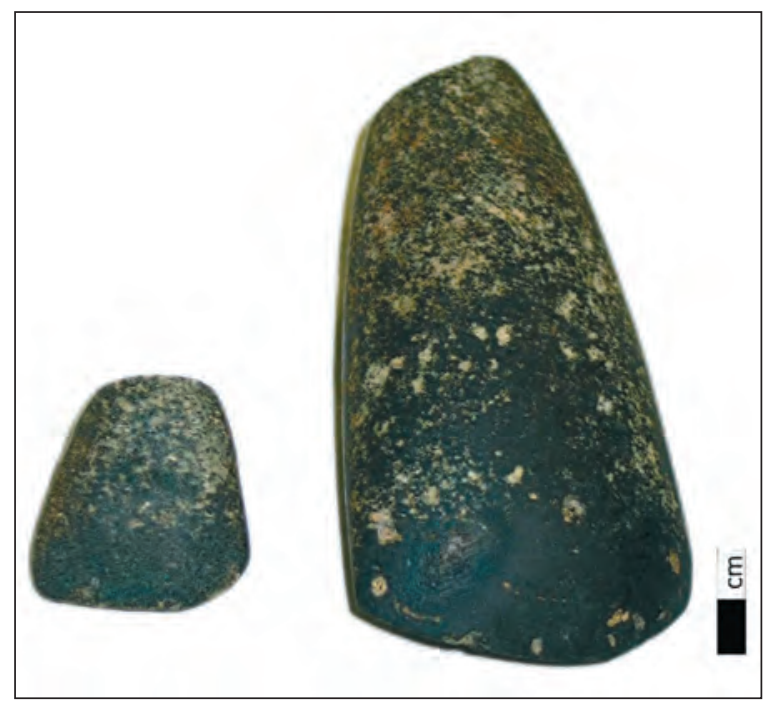

Fig. 9. Celts made of gabbro from Drakaina Cave. 


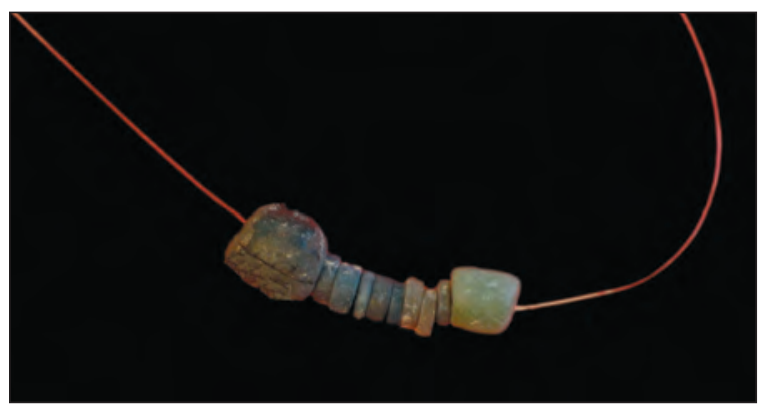

Fig. 10. Discoid and cylindrical beads made of talc from Drakaina Cave.

mental character of the site, and the special significance of the site's landscape for Neolithic society.

The making of lime plastered floors in Drakaina Cave was undoubtedly deliberate, a practice that has not been documented in any other cave of the Greek Neolithic. The floors of Drakaina Cave seem to be extended constructions, built at intervals in a similar technique - in other words, repeated in the Neolithic sequence. Through this act of deliberate construction in a cave, i.e. within an originally natural setting, people have radically affected and transformed this space (and its landscape) into a meaningful place (Thomas 1991.35). Thus, it is obvious that the construction of the floors in Drakaina was a practice of special significance. For instance, such a practice could be related to the community's intention to create new relations with the site, or to seal and 'secure' its past, or even to bury and transform it into a memory by forgetting it (Bradley 2003.224; Harrison 2004).

The floors in Drakaina point to long-life constructions, comparable to the stable built features of a domestic area. Whatever the character of this practice might be, its repeated pattern over time indicates

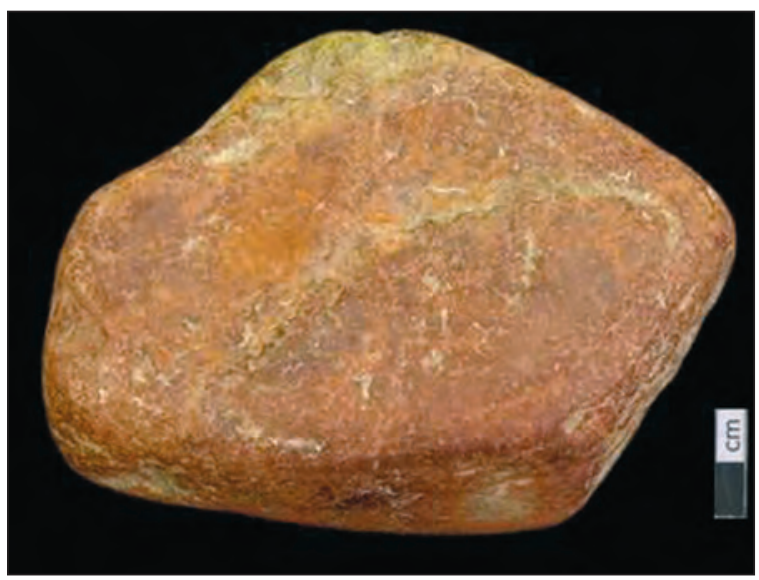

Fig. 11. Stone grinding tool coated with red dye from Drakaina Cave. a formal practice that seems to be well embedded in the tradition of its makers. Therefore, the use and (re)construction of the floors might be associated with particular social needs and/or events which had serious effects on Neolithic society (cf. Boivin 2000).

Undoubtedly, the construction of the floors itself reflects the intention of the community as a whole, or of a part of the community, to create bonds with Drakaina Cave, and, therefore, through the cave, with its socialized landscape. In this practice we may see incorporated the signature of the cave's users, whose settlements must be sought near the site. Recent surveys have recognized scatters of Neolithic finds in the broader and/or even the immediate area of the cave (Randsborg 2002). Until now no Neolithic settlement has been identified in the vicinity of Drakaina, but based on the findings of the cave itself (e.g.

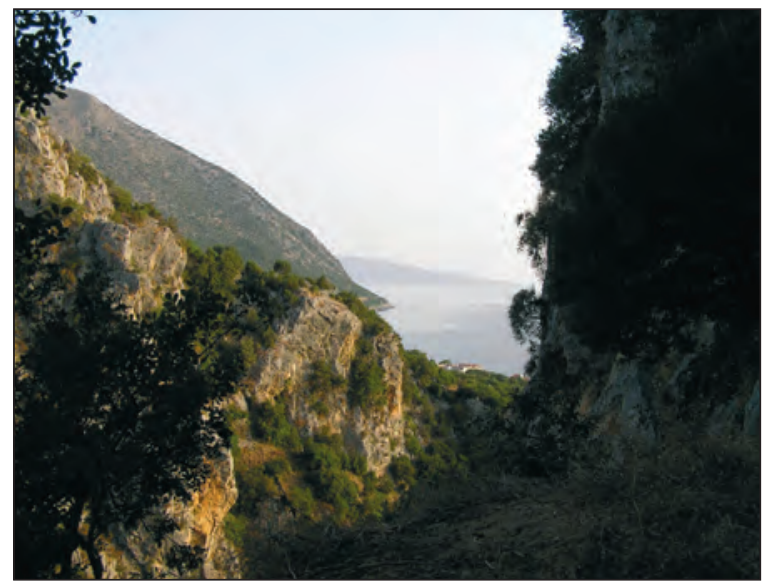

Fig. 12. View of the gorge of Poros.

ground stone tools made of various local rocks (Melfos in preparation), or the presence of large pots), it is more than likely that during the use of the cave there were settlement(s) nearby.

In fact, in the lime plastered floor construction in Drakaina we may read a system of symbols of particular meaning with which the members of the Neolithic community were familiar. This symbolic behaviour seems to have been reinforced by the deliberate deposition of architectural remains in the subsurface of the floors, as well as by the deliberate deposition of highly-fragmented decorated pottery, of various chert tools of exceptional quality, of ground stone tools marked by red pigment, and of a variety of ornaments or other special small finds related to the floor deposits. Such behaviour seems to incorporate many features of the identity of the cave users, in particular, various aspects of their social life and culture, including features of their habitation, sub- 


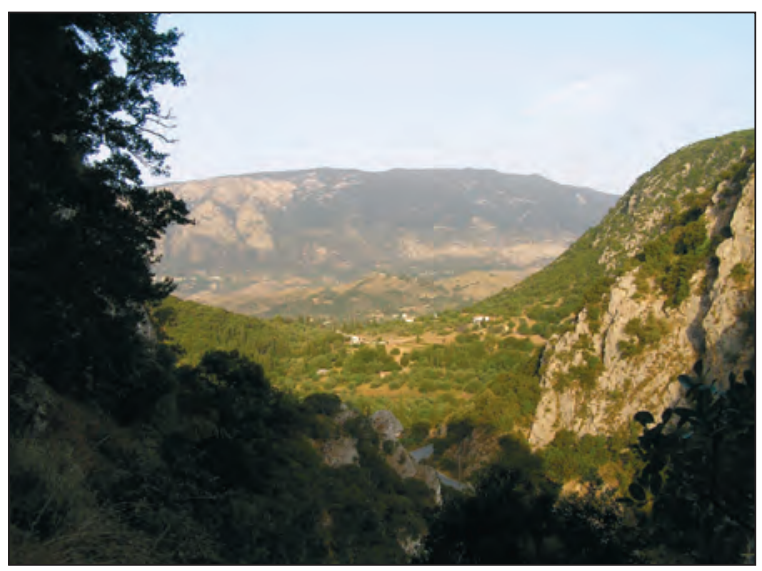

Fig. 13. Partial view of the Tzannata basin including the western part of the gorge of Poros.

sistence strategies, and complicated exchange and communication networks, which supported the reproduction of society.

The content of the Neolithic deposits in Drakaina Cave could be related to a series of events, such as ceremonies, rituals, feastings, or other kind of gatherings, which took place in the cave and which may have contributed to the formation of the character of the site and its identity, while being of essential significance for the personal and collective biographies of the social group(s) that used it. The meaning of the symbolic behaviour under discussion may be associated with the so-called 'technology of memory' (Edmonds 1999.7), i.e. to what a society can absorb, reuse and rework by means of its interaction with particular monuments, as well as with practices of special meaning. Drakaina Cave could have been a valued site, probably a monument of social memory.

Such significance could be attributed to Drakaina Cave due to its specific location in the Poros Gorge (Fig. 12), which links the coastal zone with the Tzannata Basin, a small, well-defined basin, rich in several resources, including grazing and cultivable land, water sources, woodlands, and a variety of rocks (Fig. 13). The Gorge forms an exit towards the sea on the eastern part of the island and, thus, it connects Kephalonia with the Greek mainland through the Ionian Sea, which in this region is an easily crossed channel. From this point of view, the sea was not a barrier keeping people in isolation. On the contrary, it brought people together, making it possible for them to participate in inter-regional exchange and communication networks. It is worth noting that the cultural deposits at the cave comprise almost the whole range of local resources, as well as raw materials and/or craft products (e.g. made of gabbro, obsidian, talc), which were transported to the island by sea. Based on their provenance analyses, these originated from the Pindos Mountains and more precisely, the Grevena area of Western Macedonia, from the area of Argolid in the Eastern Peloponnese (Stratouli and Melfos in press), as well as from Melos (see obsidian) and Naxos (see marble) in the Southern Aegean (Kilikoglou in preparation; Melfos in preparation).

To sum up, I view Poros Gorge as a landmark in itself, a distinct topographical feature of the landscape, as a powerful resource for the society's symbolic system, having a special significance for the creation and reproduction of social power relationships in the region (Tilley 1996). It was probably an essential component of the formation of a distinctive Neolithic culture in this area. Thus, Drakaina Cave, as part of the Gorge and its marked landscape, contributed to the formation of the biography, identity and politics of the Neolithic community in the region.

\section{ACKNOWLEDGEMENTS}

This paper is based on the Drakaina Cave research project supported by the Hellenic Ministry of Culture and the Municipality of Eleios-Pronnoi (Poros). I am particularly grateful to the Institute for Aegean Prehistory and to the I. F. Kostopoulos Foundation for their funding over the last few years. I would also like to express my gratitude to Makis Metaxas, Dimitris Vandoros, and Kostas Zapantis, as well as to other friends from Poros for their financial and moral support during the Drakaina excavations. Finally, I would like to thank Tasos Bekiaris for the information he provided on related literature. 


\section{REFERENCES}

ANDREASEN N. H. (in preparation). Chipped stones from the Late and Final Neolithic levels at Drakaina Cave, Kefalonia. A preliminary report. In G. Stratouli (ed.), Drakaina Cave on Kephalonia Island, Western Greece: A Place of Social Activity during the Neolithic.

BAILEY D. 2000. Balkan Prehistory. Exclusion, Incorporation and Identity. Routledge. London.

BARNATT J. and EDMONDS M. 2002. Places Apart? Caves and Monuments in Neolithic and Bronze Age Britain. Cambridge Archaeological Journal 12/1: 113-129.

BASSO K. H. 1996. Wisdom Sits in Places. Notes on a Western Apache Landscape. In S. Feld and K. H. Basso (eds.), Senses of Place: 53-90.

BEKIARIS T. (in preparation). The Ground Stone Tools from Drakaina Cave: Grounds for Thought. In G. Stratouli (ed.), Drakaina Cave on Kephalonia Island, Western Greece: A Place of Social Activity during the Neolithic.

BENDER B. 1998. Stonehenge - Making Space. Berg. Oxford \& New York.

BOIVIN N. 2000. Life rhythms and floor sequences: excavating time in rural Rajasthan and Neolithic Catalhöyük. World Archaeology 31/3: 367-388.

BRADLEY R. 1998. The Significance of Monuments. On the Shaping of Human Experience in Neolithic and Bronze Age Europe. Routledge. London \& New York.

2001. An Archaeology of Natural Places. Routledge. London \& New York.

2003. The Translation of Time. In R. M. van Dyke and S. E. Alcock (eds.), Archaeologies of Memory: 221-227.

CHAPMAN J. 2000. Fragmentation in Archaeology: People, Places and Broken Objects in the Prehistory of South-Eastern Europe. Routledge: London.

CHATZIOTOU E.-M., STRATOULI G. and KOTZAMBOPOULOU E. 1995. The Drakaina Cave. Recent Investigations at Poros on Kefalonia (1992-1993). Athens Annals of Archaeology 22 (1989): 31-60 (in greek with an abstract in english).
CHATZIOTOU E.-M. and STRATOULI G. 2000. Drakaina Cave in Poros of Kephalonia. Evidence for the prehistoric use of the cave and its use as a cult place during the historical times. Proceedings of the $6^{\text {th }}$ Panionian Symposium, Zakynthos, 23-27 September 1997. University Studio Press. Thessaloniki: 61-76 (in greek).

CRUMLEY C. L. 2002. Reading the land: The archaeology of settlement and land use. In P. N. Peregrine, C. R. Ember and M. Ember (eds.), Archaeology. Original Readings in Method and Practice: 298-316.

DIETLER M. and HAYDEN B. 2001. Digesting the feast-good to eat, good to drink, good to think: An introduction. In M. Dietler and B. Hayden (eds.), Feasts. Archaeological and ethnographic perspectives on food, politics and power: 1-20.

DYKE R. M. van and ALCOCK S. E. 2003. Archaeologies of Memory. An Introduction. In R. M. van Dyke and S. E. Alcock (eds.), Archaeologies of Memory: $1-13$.

EDMONDS M. 1999. Ancestral Geographies of the Neolithic. Landscapes, Monuments and Memory. Routledge. London \& New York.

GIMBUTAS M. A. 1982. The Goddesses and Gods of Old Europe, 6500-3500 BC. Myths and Cult Images. University of California. Berkley.

HARRISON S. 2004. Forgetful and memorious landscapes. Social Anthropology 12/2: 135-151.

HILL J. B. 2004. Time, scale and interpretation: 10,000 years of land use on the transjordan plateau amid multiple contexts of change. In E. F. Athanassopoulos and L. Wandsnider (eds.), Mediterranean Archaeological Landscapes. Current Issues: 125142.

HODDER I. 1984. Burials, houses, women and men in the European Neolithic. In D. Miller and C. Tilley (eds.), Ideology, Power and Prehistory: 51-68.

1986. Symbols in Action. Ethnoarchaeological Studies of Material Culture. Cambridge University Press. Cambridge.

1990. The Domestication of Europe. Structure and Contingency in Neolithic Societies. Blackwell. Oxford. 
(ed.). 1991. The Meaning of Things. Material Culture and Symbolic Expression. One World Archaeology Series 6. Unwin Hyman. London.

1995. Theory and Practice in Archaeology. Routledge. London.

KARKANAS P. 2002. Micromorphological studies in Greek prehistoric sites: New insight in the interpretation of the archaeological record. Geoarchaeo$\log y$ 17: 237-259.

KARKANAS P. and STRATOULI G. (in preparation). Neolithic lime plastered floors in Drakaina Cave, Kephalonia Island, Western Greece: Evidence of the significance of the site.

KILIKOGLOU V. (in preparation). Sourcing obsidian from Drakaina Cave, Kephalonia Island, Western Greece. In G. Stratouli (ed.), Drakaina Cave on Kephalonia Island, Western Greece: A Place of Social Activity during the Neolithic.

KIRIATZI E. (in preparation). Ceramic traditions and people in a neolithic cave: Analysis of Late and Final Neolithic pottery from Drakaina Cave, Kephalonia Island, Western Greece. In G. Stratouli (ed.), Drakaina Cave on Kephalonia Island, Western Greece: A Place of Social Activity during the Neolithic.

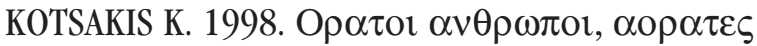

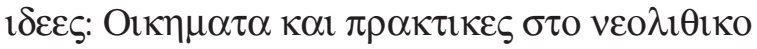
$\Sigma \varepsilon \sigma \kappa \lambda \mathrm{o}$. In The prehistoric research in Greece and its Perspectives: Theoretical and Methodological Considerations, Proceedings of International Symposium in the memory of D. R. Theocharis, Thessaloniki Kastoria, 26-28 November 1998. University Studio Press. Thessaloniki: 155-161 (in greek).

1999. What Tells Can Tell: Social Space and Settlement in the Greek Neolithic. In P. Halstead (ed.), Neolithic Society in Greece. Sheffield Studies in Aegean Archaeology, 2: 66-76.

KOTZAMBOPOULOU E. (in preparation). Dinner at the cave: Aspects of the Late Neolithic faunal assemblage of Drakaina Cave, Kephalonia, Ionian Islands. In G. Stratouli (ed.), Drakaina Cave on Kephalonia Island, Western Greece: A Place of Social Activity during the Neolithic.

MAPS - Figs. 1-2 on-line http://www.greeklandscapes. com (satellite image courtesy of http://www.visible earth.nasa.gov).
MELFOS V. (in preparation). Characterization of lithic artefacts from the neolithic deposits of Drakaina Cave, Kephalonia, Ionian Islands: A petrographicgeochemical approach for determination of raw materials and sources. In G. Stratouli (ed.), Drakaina Cave on Kephalonia Island, Western Greece: A Place of Social Activity during the Neolithic.

METAXAS 0. (in preparation). Projectile points from the Late and Final Neolithic levels of Drakaina Cave, Kephalonia. In G. Stratouli (ed.), Drakaina Cave on Kephalonia Island, Western Greece: A Place of Social Activity during the Neolithic.

NANOGLOU S. 2001. Social and monumental space in Neolithic Thessaly. European Journal of Archaeology 4/3: 303-322.

NIKOLOVA L. (ed.). 2003. Early Symbolic Systems for Communication in Southeast Europe, Vols. $1 \& 2$. BAR International Series 1139.

PARKER-PEARSON M. and RICHARDS C. 1994. Architecture and Order. Approaches to Social Space. Routledge. London.

PEARSON M. P. 2003. Food, Identity and Culture: An Introduction and Overview. In M. P. Pearson (ed.), Food, Culture and Identity in the Neolithic and Early Bonze Age. BAR S1117: 1-30.

RANDSBORG K. (ed.). 2002. Kephallenia - Archaeology \& History. The Ancient Greek Cities. Acta Archaeologica (Suppl.), Vol. IV: 1+2.

RENFREW C. 1984. Approaches to Social Archaeo$\log y$. Edinburgh University Press. Edinburgh.

SARPAKI A. (in preparation). Drakaina Cave at Poros in Kephalonia: A preliminary report on the progress of the archaeobotanical research. In G. Stratouli (ed.), Drakaina Cave on Kephalonia Island, Western Greece: A Place of Social Activity during the Neolithic.

SÉFÉRIADÈS M. 1995. Le commerce des spondyles de la Mer Égée à la manche. Archéologia 309 (Février 1995): 42-50.

STRATOULI G. (ed.). (in preparation). Drakaina Cave on Kephalonia Island, Western Greece: A Place of Social Activity during the Neolithic.

STRATOULI G. and GOUDI A. (in preparation). Neolithic Painted Pottery from Drakaina Cave, Kepha- 
lonia, Ionian Islands. In G. Stratouli (ed.), Drakaina Cave on Kephalonia Island, Western Greece: A Place of Social Activity during the Neolithic.

STRATOULI G. and MELFOS V. (in press). Exchange networks in the Neolithic of Greece: Gabbro and talc objects from Drakaina Cave, Kephalonia Island, Western Greece. Proceedings of the $4^{\text {th }}$ Symposium on Archaeometry of the Hellenic Society for Archaeometry, 28-31 May 2003, Athens. B.A.R.

STRATOULI G., FACORELLIS Y. and MANIATIS Y. 1999. Towards understanding the Late Neolithic and the Chalcolithic in the Ionian Islands, Western Greece: $14 \mathrm{C}$ evidence from the "Cave of Drakaina", Poros, Cephalonia. In J. Evin, Chr. Oberlin, J.P. Daugas and J.-F. Salles (eds.), Actes du 3ème Congrès International, Lyon 6-20 avril 1998, 14C et Archéologie, Memoires de la Société Préhistorique Française 26, 1999 et Supplément 1999 de la Revue d' Archéométrie: 273-278.

THEODOROPOULOU T. (in preparation). Sea faunal remains from the neolithic layers of Drakaina Cave. A preliminary report. In G. Stratouli (ed.), Drakaina Cave on Kephalonia Island, Western Greece: A Place of Social Activity during the Neolithic.
THOMAS J. 1991. Understanding the Neolithic. Routledge. London.

1996. Time, Culture and Identity. Routledge. London.

2001. Archaeologies of Place and Landscape. In I. Hodder (ed.), Archaeological Theory Today: 165-186.

TILLEY C. 1994. A Phenomenology of Landscape. Places, Paths and Monuments. Berg. Oxford \& Providence.

1996. The Powers of Rocks: Topography and Monument Construction on Bodmin Moor. World Archaeology 28/2: 161-176.

TUAN Y.-F. 1977. Space and Place. The Perspective of Experience. University of Minnesota Press. Minneapolis \& London.

WHITTLE A. 1996. Europe in the Neolithic. The Creation of New Worlds. Cambridge University Press. Cambridge.

2003. The Archaeology of People. Dimensions of Neolithic Life. Routledge. London. 